\title{
Use of Frozen Leaves for Morpho- anatomical Characterization of Nectandra megapotamica (Spreng.) Mez., Lauraceae
}

\author{
Leonardo Severo da Costa ${ }^{1^{*}}$ \\ https://orcid.org/0000-0003-2891-3429
}

\author{
Lia Rejane Silveira Reiniger ${ }^{2}$ \\ https://orcid.org/0000-0002-3243-671X \\ Helena Trindade ${ }^{3}$ \\ https://orcid.org/0000-0002-1209-2622
}

\section{Berta Maria Heinzmann 4 \\ https://orcid.org/0000-0002-6509-949X}

\author{
Nadia Helena Bianchini ${ }^{4}$ \\ https://orcid.org/0000-0002-7035-6075
}

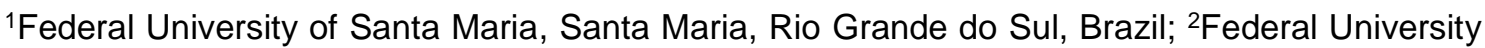
of Santa Maria, Department of Fitotecny, Santa Maria, Rio Grande do Sul, Brazil; 3University of Lisbon, Faculty of Sciences of the University of Lisbon, Department of Plant Biology, Lisboa, Portugal; ${ }^{4}$ Federal University of Santa Maria, Forest Science Center, Santa Maria, Rio Grande do Sul, Brazil.
\end{abstract}

Received: 2018.05.09; Accepted: 2019.03.21.

*Correspondence: leonardosev@gmail.com; Tel.: +55-55-999060049 (LSC).

\section{HIGHLIGHTS}

- It was possible to obtain a morpho-anatomical characterization from frozen leaf samples.

- Typical structures of the family Lauraceae described by other authors were identified.

- Secretion and storage of essential oil occurs in secretory cavities.

Abstract: Nectandra megapotamica (Spreng.) Mez. it is a native tree species of the Atlantic Forest, commonly known as canela-preta. The species has some antiinflammatory, antitumor and antirheumatic properties among others. In this work the use of frozen plant material for microscopy analysis was tested. In addition, the leaf morpho-anatomy of the species was characterized which allowed to perform a structural description and to identify structures of secretion and storage of essential oil. The plant material was prepared for analyzes in optical, fluorescence and scanning electron microscopy. The leaf anatomy shows glabrous epidermis, unistratified, paracytic stomata, absence of trichomes, polyhedral epidermal cells. Some typical family characteristics were observed as a closed arc-shaped bicollateral bundle 
vascular system and dorsiventral mesophyll. The structures of secretion and storage of essential oil were identified as secretory cavities.

Keywords: forest species; new methodology; leaf anatomy; essential oil; secretory cavities

\section{INTRODUCTION}

The Lauraceae family comprises 52 genera and approximately 3000 species. It occurs predominantly in tropical and subtropical regions, being exceptionally found in temperate regions [1, 2, 3]. In Brazil, it is represented by 22 genera and about 400 species that inhabit mostly the rainforests, restingas and cerrado [4].

Nectandra megapotamica (Spreng.) Mez (Lauraceae), known popularly as canelapreta, is a forest species native to Brazil with a large occurrence in the Atlantic Forest. It is a species that has important characteristics and can be used for various purposes. In recent years its non-wood products, in particular essential oils are becoming more important.

The essential oil of Nectandra megapotamica has already revealed to have microbial activity against Staphylococcus aureus, anti-inflammatory and antitumoral activity, indicating its pharmacological potential [5]. Some organ-based preparations of this species have been shown to inhibit hemolytic, coagulant and proteolytic activities of venom of Bothrops diporus [6]. The essential oil showed also an anesthetic effect on Centropomus parallelus [7], as well as antifungal and antimicrobial activities. Medicinal properties can be induced by many different parts of a plant including leaves, roots, bark, fruit, seeds, flowers. In Nectandra, the leaves are used in the treatment of cough, flu and as a sedative [8]; bark as analgesic and anti-rheumatic [9] and also in abscesses [8]; and roots, such as analgesic and anti-inflammatory [10].

Therefore, several researches are being developed with Nectandra, demonstrating its pharmacological potential; however, no study was performed on the morphoanatomy of the leaves of the species. Traditionally, microscopy studies use fresh plant material, however, in certain situations it is not possible to carry out the tests immediately after collection, as in the case of a large distance between the collection site and the laboratory. There is still the possibility of the absence of plant material in certain months of the year, in the case of working with deciduous species.

In this sense, the objective of the present study was to analyze the potential use of plant samples stored in ultrafreezer to characterize the species Nectandra megapotamica (Spreng.) Mez. regarding its leaf anatomy and to identify secretory structures and storage of essential oils.

\section{MATERIAL AND METHODS}

The experiments of optical microscopy, fluorescence and scanning electron microscopy were carried out at the microscopy facilities lab of the Plant Biology Department, Faculty of Sciences of the University of Lisbon.

The plant material used in the microscopy assays were stored in ULT freezer for 3 months. No dehydrated or freeze-drying procedure was used. For optical and fluorescence microscopy a protocol with Red Sudan IV dye was used. The leaf sections were immersed in saturated solution of $0.3 \%$ Red Sudan IV in $70 \%$ Ethanol $(\mathrm{ETOH})$, for $15 \mathrm{~min}$. Two quick washes were performed, one in $70 \%$ ethanol and other in distilled water $\left(\mathrm{dH}_{2} \mathrm{O}\right)$, proceeding with the assembly of the blades.

For Scanning Electron Microscopy (SEM), the samples were chemically fixed with $1 \%$ Glutaraldehyde (GA) in $0.05 \mathrm{M}$ sodium cacodylate (CAC) buffer, $\mathrm{pH} 7.2$, during 45 min at room temperature (the volume used was necessary to cover the samples). After, the fixative was replaced by a new solution of $1 \%$ Glutaraldehyde (GA), remaining for $2 \mathrm{~h}$ at room temperature. Then, three washes were carried out with $0.05 \mathrm{M}$ Sodium 
cacodylate buffer (CAC), for 5min. After, post-fixation was performed with a $1 \%$ Osmium tetroxide (OsO4) for $2 \mathrm{~h}$.

Dehydratation was performed with a graded acetone series by subsequent exchanges of dilutions in distilled water (a 10\%, 20\%, 30\%, until 100\%) and drying by the critical point method through carbon dioxide (CPD 030, Balzers). Finally, the samples were mounted on a stub (several orientations) and received a coating of gold (MED 010, Balzers).

\section{RESULTS AND DISCUSSION}

From the frozen samples in ultra-freezer it was possible to obtain high quality blades. Although frozen, the leaf remained ultrastructurally intact post-thaw, which allowed to perform the morpho-anatomical characterization of the species. There is no research in the scientific literature describing the use of frozen samples in histological and histochemical tests. This study demonstrates the possibility of using this type of samples, which was previously considered inappropriate.

Based on the images obtained by optical and fluorescence microscopy, it was possible to perform a histological and histochemical characterization for total lipids of the species under study. The leaf blade presents glabrous epidermis, uniestratified, without trichomes, being composed of a single layer of cells on both faces. In frontal view of the adaxial face (Fig. 1), the epidermal cells are of polyhedral shape, with straight anticlinal walls of irregular sizes and thickened walls. In the abaxial face, the stomatal type cannot be clearly visualized, appearing to be of the paracytic type with guard cells at the same level of the epidermis (Fig. 2). Similar pattern was reported by another research with the same species [11], in which the epidermal cells exhibit straight anticlinal walls, stomata and guard cells almost imperceptible (100x). The cuticle and the cutinized portion of epidermal cells are thin, and the cutinization of the epidermal cells occurs only in the external periclinal walls.

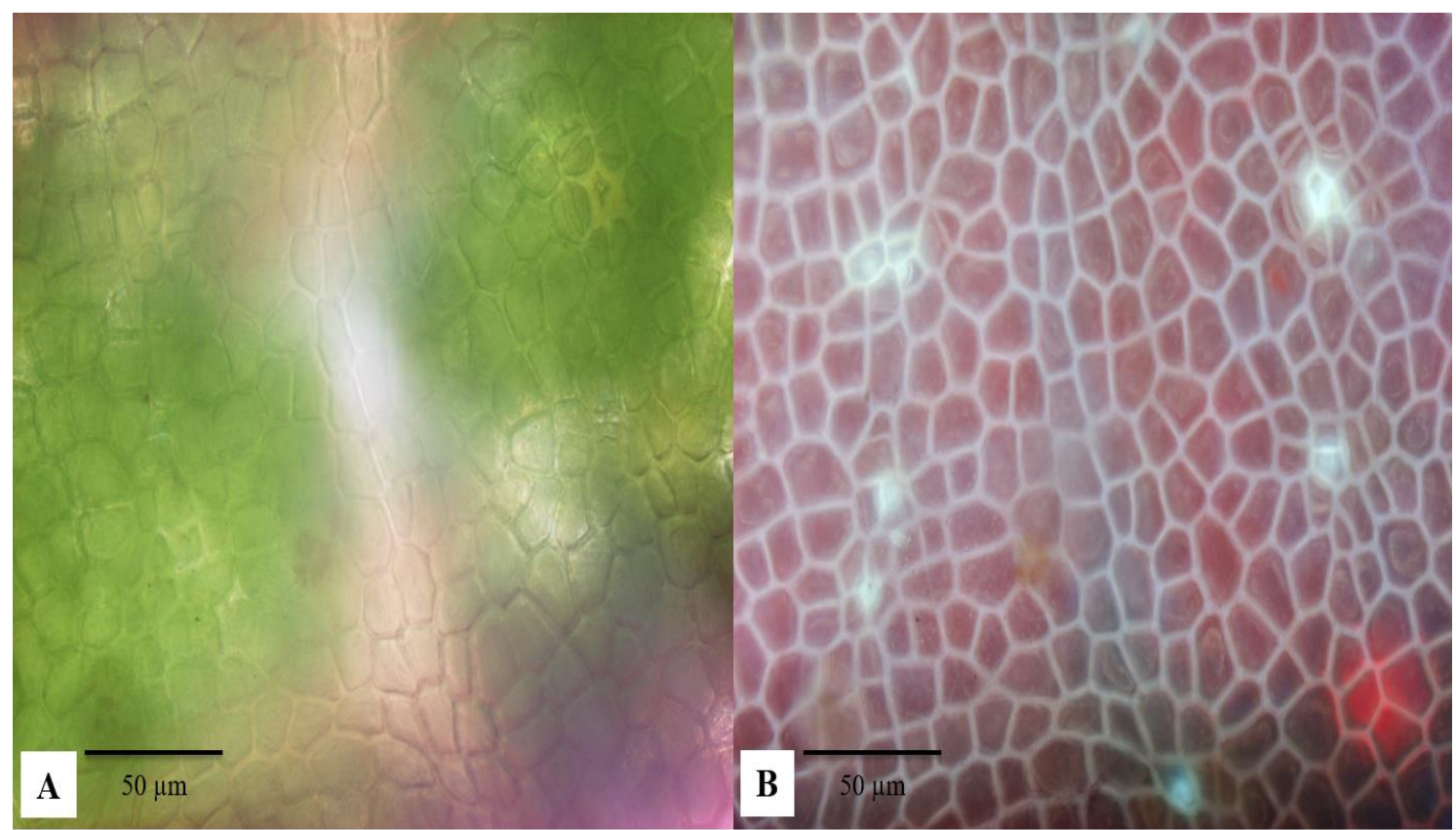

Figure 1. In front view, adaxial face of epidermis of Nectandra megapotamica (Spreng.) Mez. A) Image taken under visible light; B) Image taken with a fluorescence microscope with UV filter. 


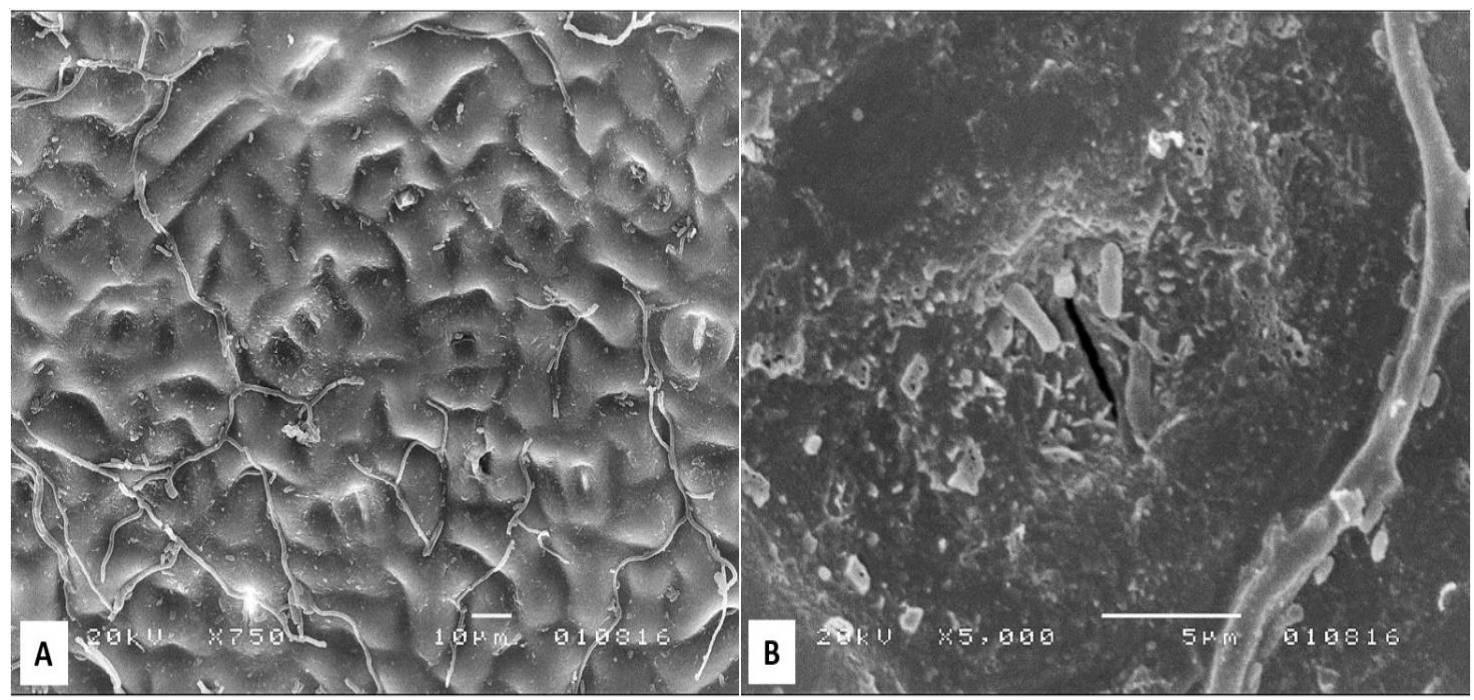

Figure 2. In front view, abaxial face of epidermis of Nectandra megapotamica (Spreng.) Mez., image obtained by SEM. A) Abaxial face of epidermis. B) Stoma in the abaxial face.

The mesophyll is dorsiventral, corresponding to the characteristic pattern of the family Lauraceae [12]. It presents a palisade parenchyma layer near the adaxial surface and four to six layers of spongy parenchyma (Fig. 3). Together with the palisade parenchyma, there are secretory cells of rounded or elliptical shape, located just below the adaxial epidermis and in subepidermal space. These cells have their lumen almost totally filled with oil and do not present chloroplasts. Histochemical test using Sudan IV (data not show) did not detect the presence of lipids in the walls of secretory cells. The secretory cells are secretory cavities because they occur in spherical format. These structures consist of large intercellular spaces that are formed either by the separation of the walls of neighboring cells, or by the disintegration of cells [13].

A very similar pattern of secretory cavity has been reported for other species of the genus Nectandra. In Nectandra lanceolata Nees et Mart. ex Nees, popularly known as canela-amarela, essential oil secretory structures were identified, distributed in the parenchyma randomly., including in the layers closest to the epidermis. In Nectandra rigida (H.B.K) Nees, popularly known as canela-ferrugem, the essential oil secretory structures were located in the subepidermal strata, randomly distributed among the cells of the palisade parenchyma [14].

The presence of mucilage and essential oil secretory structures is very common in species of the Lauraceae family. These structures were identified in almost twenty genera of the family, these structures being characterized by a spherical shape, with a suberized wall and often appear as translucent points of the leaves [15]. In some blades, the presence of translucent spots could be observed (Fig. 1), both in visible light and in fluorescence microscopy with the UV filter. However, this feature cannot be viewed without the aid of a microscope. To validate the correlation of the translucent points with the secretory structures present in the species it is necessary to perform new blades and analyzes.

Structures containing essential oils or mucilage in species of the family Lauraceae have been reported by several authors $[16,17,15,18,19]$. These structures can occur simultaneously in the same plant in several families of Dicotyledons [20]. Essential oil or mucilage cells can be derived from identical initials and may even replace each other ${ }^{21}$. The mucilaginous cells occur in the leaves of the genera Persea, Phoebe, Ocotea, Nectandra, Sassafras and Litsea [16]. The mucilaginous cells are similar in size, shape and distribution to the oleifers, being found in at least fourteen genera. 


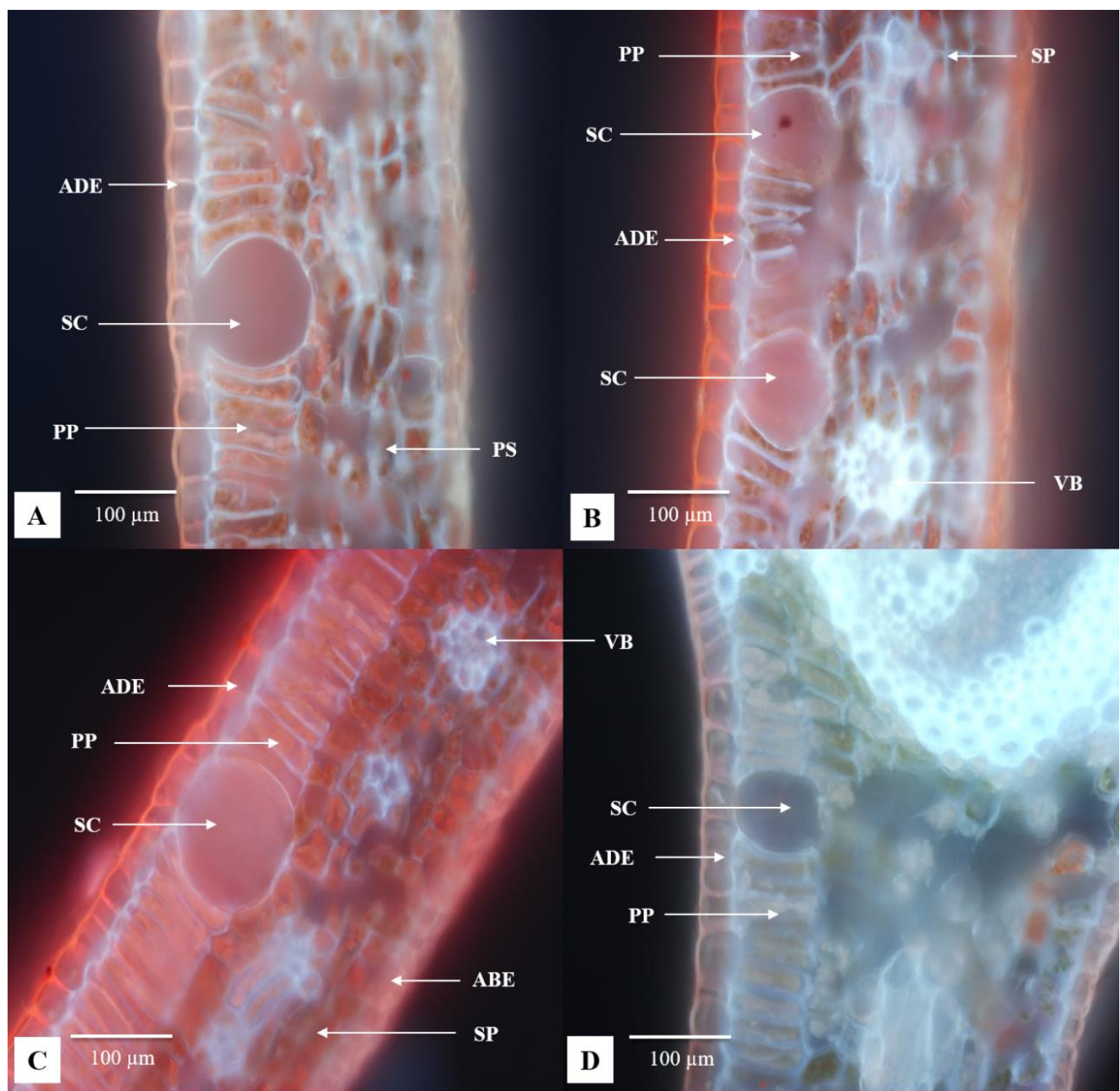

Figure 3. Leaf blade of Nectandra megapotamica (Spreng.) Mez. (transversal section) obtained by fluorescence microscopy: ADE (adaxial epidermis), ABE (abaxial epidermis), PP (palisade parenchyma), SP (spongy parenchyma), SC (secretory cavity), VB (vascular bundle).

The observation of the leaf blade by SEM (Fig. 4) showed the same structures and secretory cavities depicted in Fig. 3, however in another perspective. Figure 5, showed the secretory cavity and its surrounding with a higher level of detail. The epidermal cells located above the secretory structures do not have distinctive characteristics allowing differentiation from the surrounding cells. Thus, the secretory cavities are not amenable to recognition simply by visualization of the epidermis. 

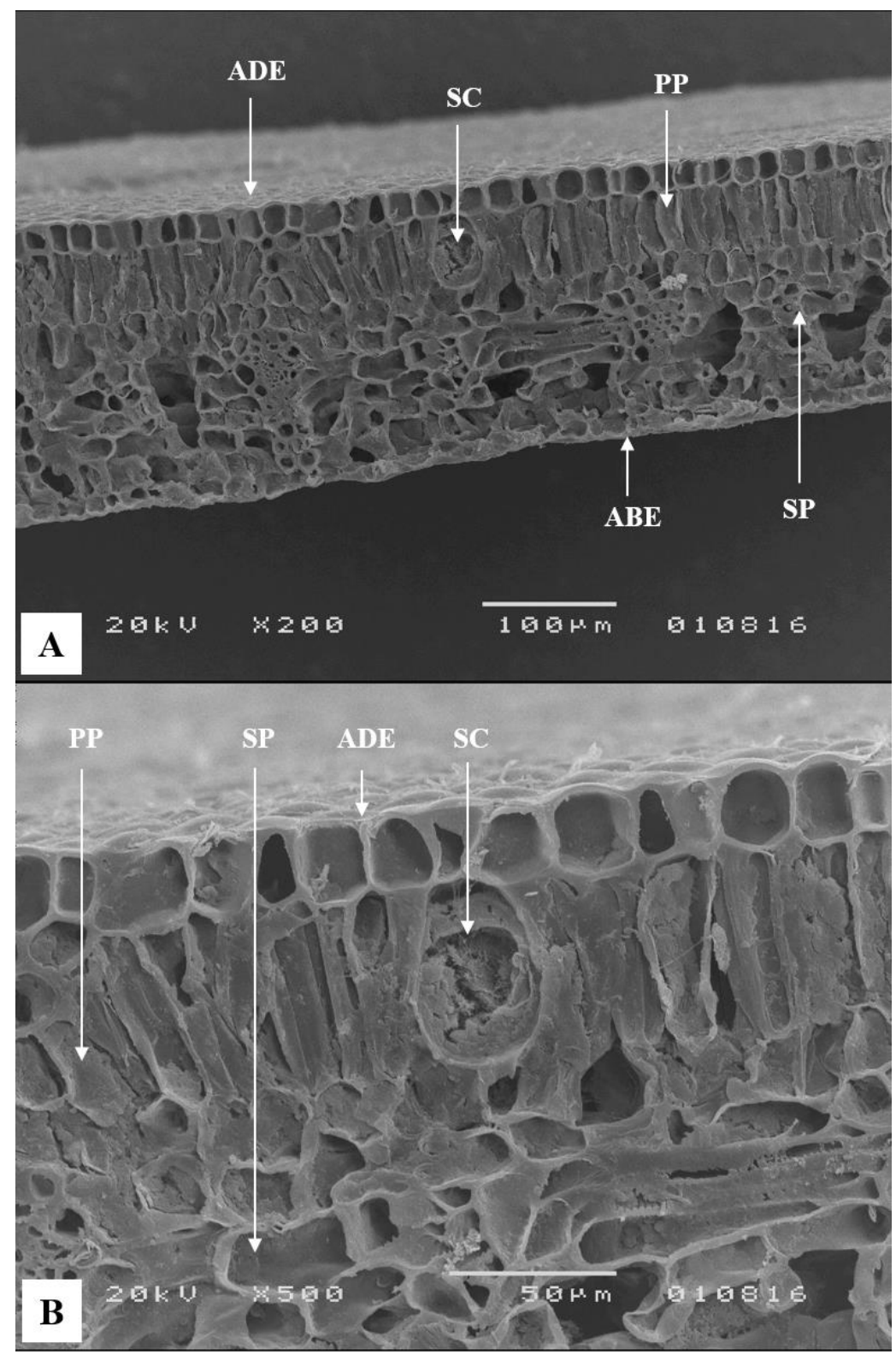

Figure 4. A) Aspect of leaf blade in frontal view; B) Aspect of the leaf blade with emphasis on the secretory cavity. ADE (adaxial epidermis), ABE (abaxial epidermis), PP (palisade parenchyma), SP (spongy parenchyma), SC (secretory cavity). 




Figure 5. Leaf blade of Nectandra megapotamica (Spreng.) Mez. (transversal section), with focus on the secretory cavity and its surrounding, obtained by SEM. ADE (adaxial epidermis), PP (palisade parenchyma), SC (secretory cavity).

In relation to the central vein, this is presented in a slightly convex / concave shape (Fig. 6 and 7). The vascular system is well defined and organized in a closed arc, with the phloem at the two poles of the xylem, characterizing the vascular system as bicollateral. The occurrence of a vascular system in arc format is characteristic in many genera of the family Lauraceae [22].

The phloem of the abaxial region is strengthened by contact with sclerenchymatic fibers. Among these fibers and the abaxial epidermis of the primary and secondary veins there are usually four layers of angular collenchyma. Single crystals occur mainly in the spongy parenchyma. Dispersed in the mesophyll occur cells containing bacterial colonies. 


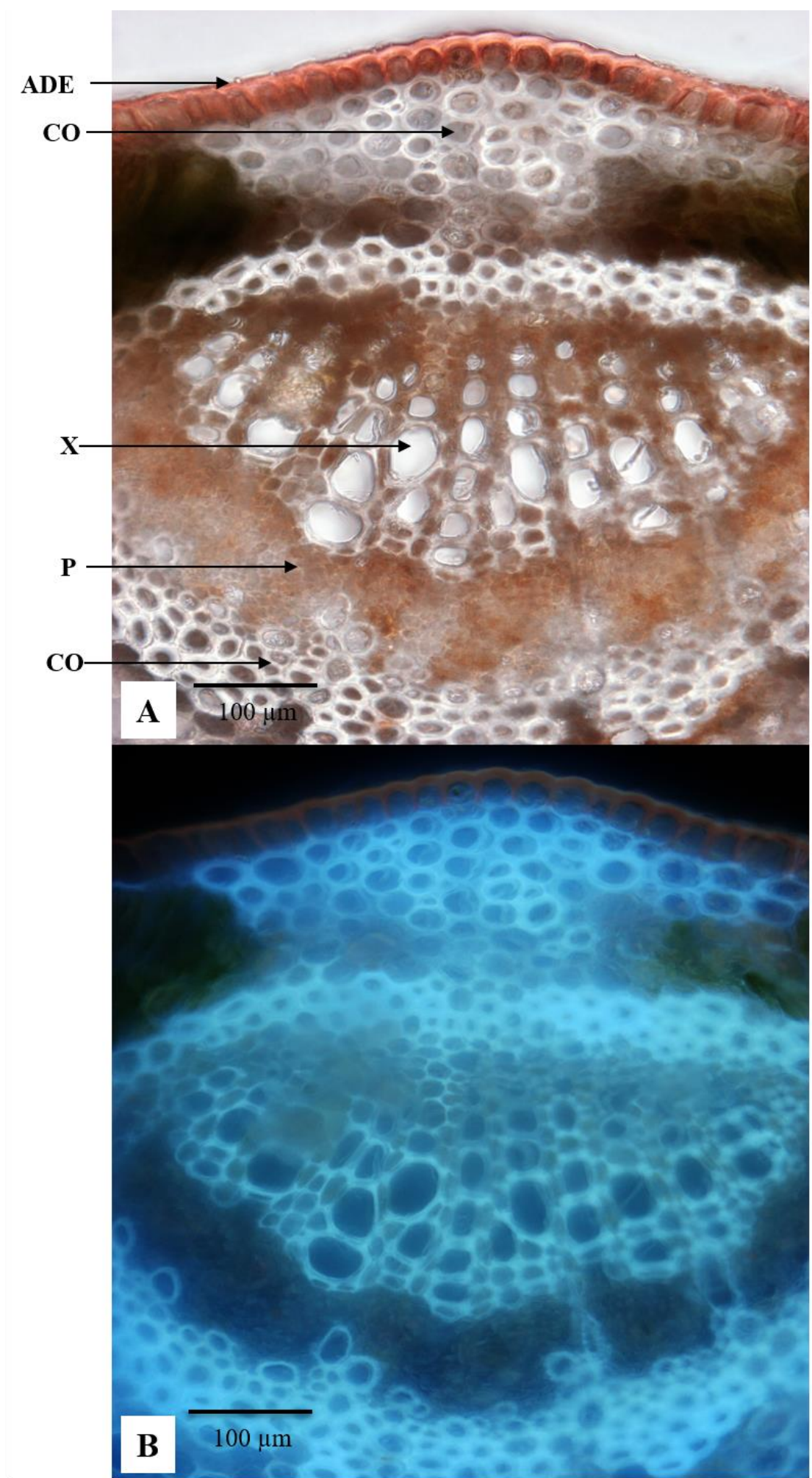

Figure 6. Transversal section of the central vein of leaf tissues of Nectandra megapotamica (Spreng.) Mez. A) Aspect of the central vein in optical microscopy; B) Aspect of the central vein in fluorescence microscopy with UV filter. AE (adaxial epidermis), P (phloem), X (xylem), SP (spongy parenchyma), $\mathrm{CO}$ (collenchyma). 

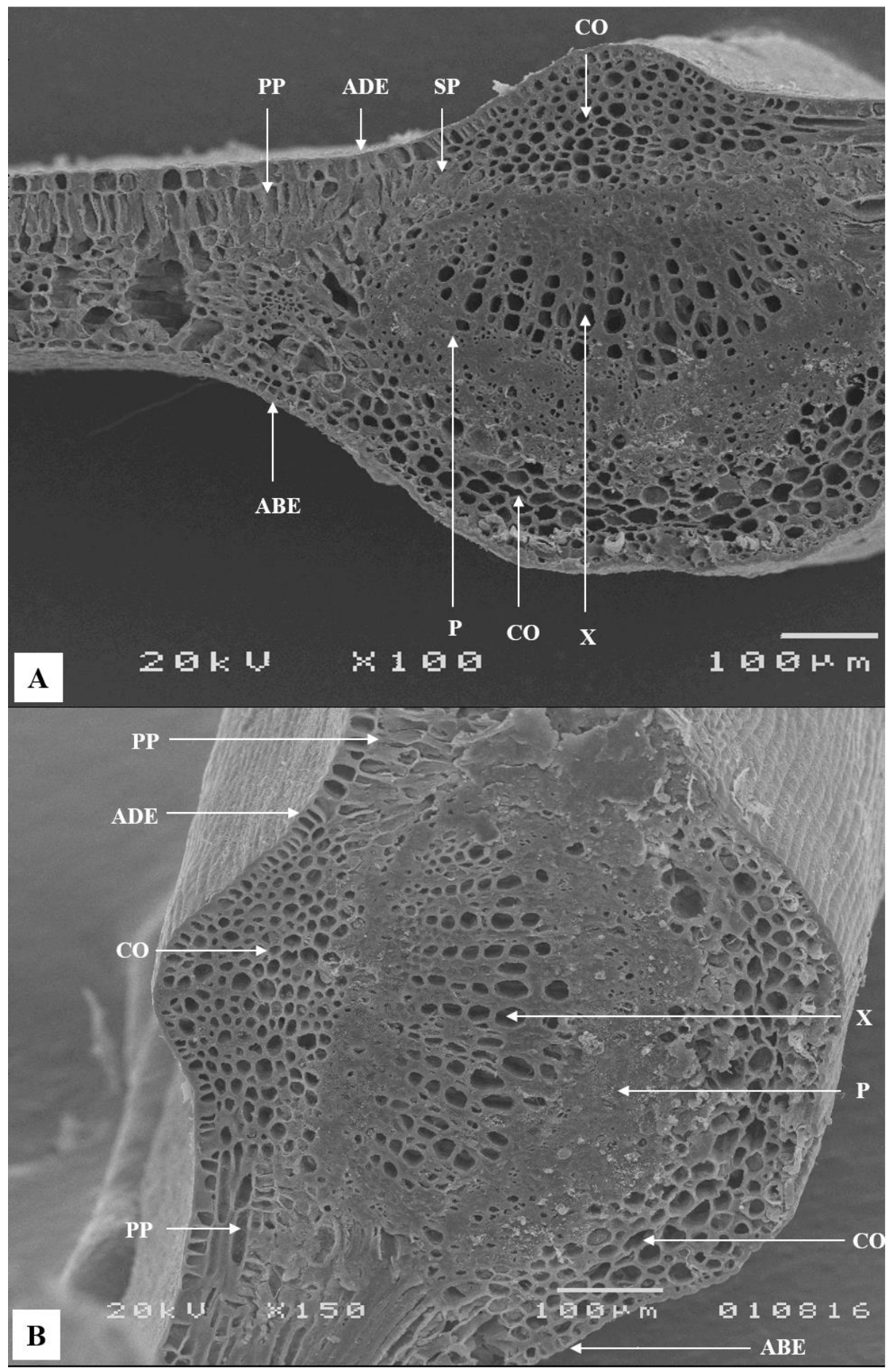

Figure 7. Transverse section of the central vein of leaf tissues of Nectandra megapotamica (Spreng.) Mez. A) Aspect of the central vein obtained by SEM; B) Aspect of central vein angled. ADE (adaxial epidermis), P (phloem), X (xylem), SP (spongy parenchyma), PP (palisade parenchyma), CO (collenchyma).

\section{CONCLUSION}

The observations performed in the microscopy, although using frozen vegetable samples, allowed the obtention of an initial description for the species, in which typical structures of the family Lauraceae already described by other authors were identified. In general, the morpho-anatomical characterization of $N$. megapotamica leaf consists of glabrous epidermis, uniestratified, paracytic stomata, absence of trichomes and polyhedral epidermal cells. Vascular system consists of a closed arc-shaped 
bicollateral bundle, mesophyll is dorsiventral and presence of secretory cavities. It was not possible to identify any exclusive structure for Nectandra megapotamica. Additional histological and histochemical tests based on the chemical composition of essential oils of the species under study, can provide more detailed characterization, especially with regard to the secretory and storage structures of these volatile substances.

Acknowledgments: Thanks are due for the financial support to CESAM (UID/AMB/50017/2019), to FCT/MCTES through national funds, and the co-funding by the FEDER, within the PT2020 Partnership Agreement and Compete 2020.

\section{REFERENCES}

1. Barroso GM, et al. Sistemática de Angiospermas do Brasil, 2rd ed.; UFV, Viçosa, Brazil, 2002.

2. Ribeiro JELS, Hopkins MJG, Vicentini A. Flora da Reserva Ducke: Guia de Identificação das Plantas Vasculares de uma Floresta de Terra-Firme na Amazônia Central, Inpa-DFID, Manaus, Brazil, 1999.

3. Rohwer JG. Lauraceae: Nectandra. Flora Neotropica. 1993;60:1-332.

4. Lorenzi H, Souza VC. Botânica sistemática: guia ilustrado para identificação das famílias de Fanerógamas nativas e exóticas no Brasil, baseado em APG II. 2rd ed.; Instituto Plantarum, Nova Odessa, Brazil, 2008.

5. Apel MA, et al. Screening of the biological activity from essential oils of native species from the atlantic rain forest (São Paulo - Brazil). Pharmacology. 2006;3:376-83.

6. Torres AM, et al. Nectandra megapotamica (Spreng.) Mez.: phytochemical characterization and neutralizing effect on Bothrops diporus venom. J Essent Oil Res. 2014;26:197-203.

7. Tondolo JSM, et al. Anesthesia and transport of fat snook Centropomus parallelus with the essential oil of Nectandra megapotamica (Spreng.) Mez. Neotrop Ichthyol. 2013;11:667-74.

8. Alves EO, et al. Levantamento etnobotânico e caracterização de plantas medicinais em fragmentos florestais de Dourados-MS. Ciência Agrotecnologia. 2008;32:651-8.

9. Da Silva Filho AA. et al. In vitro antileishmanial and antimalarial activities of tetrahydrifuran liganans isolated from Nectandra megapotamica (Lauraceae). Phytother Res 2008; 22:1307-10.

10. Mello NTK, Dias IEC, Yoshida M. Chemical constituents of Nectandra saligna Nees (Lauraceae). Revista Cubana de Plantas Medicinales. 2005;10:319.

11. Ceolin GB, Rosito JM, Canto-Dorow TS. Leaf surface characters applied to Lauraceae taxonomy in a seasonal forest of southern Brazil. Braz Arch Biol Techn. 2009;52:1453-60.

12. Metcalfe CR, Chalk L. Anatomy of the Dicotyledones: leaves, stem and wood in relation to taxonomy with notes on economic uses, $4^{\text {th }}$ ed.; Clarendon Press, Oxford, London, 1972.

13. Svoboda K. The Biology of Fragrance. Aromatherapy Quarterly. 1996;49:25-8.

14. Marques CA. Anatomia foliar aplicada à taxonomia de espécies de Lauraceae Lind. Doctorated, Universidade Federal de Viçosa, Viçosa, 2001.

15. Metcalfe CR. Anatomy of the dicotyledons: magnoliales, illiciales, and laurales, 2th ed.; Clarendon Press, Oxford, London, 1987.

16. Solereder H. Systematic Anatomy of the Dicotyledons, Claredon Press, Oxford, London, 1908.

17. Esau K. Anatomia das plantas com sementes, Edgard Blücher, São Paulo, Brazil, 1960.

18. Buvat, R. Ontogeny, cell differention and structure of vascular plants, Springer-Verlag, New York, USA, 1989.

19. Toledo MGT. Estudo botânico e fitoquímico de Ocotea odorifera (Vell.) Rohwer. (Lauraceae) da região metropolitana de Curitiba. Master, Universidade Federal do Paraná, Curitiba, 2000.

20. Baas P, Gregory M. A survey of oil cells in the dicotyledons with a comments on their replacement by and joint occurence with mucilage cells. Israel J Bot. 1985; 34:167-86. 
21. Hickey LJ. A revised classification of the architecture of dicotyledonous leaves. In: Anatomy of the Dicotyledons, 2nd ed; C. Metcalfe \& L. Chalk (eds.); Clarendon Press, Oxford, London, 1979, volume 1, pp. 25-39.

22. Metcalfe CR, Chalk L. Anatomy of the Dicotyledons, Claredon Press, Oxford, London, 1950.

(C) (1) (5) 2018 by the authors. Submitted for possible open access publication EY NC BY NC) license (https://creativecommons.org/licenses/by-nc/4.0/). 